\title{
Fitz-Hugh-Curtis syndrome in elderly male patient. Case and literature review
}

\author{
Síndrome de Fitz-Hugh-Curtis en un paciente varón anciano. Caso y revisión de la \\ literatura
}

\author{
Miguel A. Freiria-Eiras* and Cristina Varela-Lamas \\ Department of Digestive System Surgery, Hospital HM Rosaleda, Santiago de Compostela, A Coruña, Spain
}

\begin{abstract}
\end{abstract}
Fitz-Hugh-Curtis syndrome (FHCS) is the inflammation of the hepatic capsule without affecting the parenchyma, which is associated with a pelvic inflammatory disease. There have been very few cases in men. The main symptom is abdominalapain in the right upper quadrant, which can be confused with a bile duct disorder. Strong violin string-like adhesions between the diaphragm and the liver are characteristic. In the study concerned, it is reported the case of an 81-year-old man who uhidergoes a laparoscopic cholecystectomy for recurrent pancreatitis. During surgery, the typical violin string-like adhesions are found and sectioned. The patient tests positive for Chlamydia trachomatis antibodies. Only nine cases in men have been reported in FHCS literature. This syndrome is frequently confused with infectious biliary tract disease, so the patient should undergo a surgery to diagnose when the characteristic adhesions are found. If the disease is suspected by the additional tests, it can be treated with antibiotics.

KEY WORDS: Cholecystectomy. Fitz-Hugh-Curtis. Chlamydia.

\section{Resumen}

El síndrome de Fitz-Hugh-Curtis (FHCS) es la inflamación de la cápsula hepática sin afectación del parénquima asociada a una enfermedad pélvica inflamatoria. Hay muy pocos casos descritos en varones. El síntoma característico es el dolor abdominal en el cuadrante superior derecho, que hace que se confunda el cuadro con una enfermedad de la vía biliar. Son características las adherencias fuertes entre el diafragma y el hígado en forma de "cuerda de violín». Presentamos el caso de un varón de 81 años que se somete a una colecistectomía laparoscópica por pancreatitis de repetición. Durante la cirugì se encuentran las características adherencias en "cuerda de violín", que se seccionan. El paciente da positivo para anticuejpos contra Chlamydia trachomatis. Hay nueve casos descritos en la literatura de FHCS en varones. Este síndrome se confünde muchas veces con patología infecciosa biliar, lo que nos obliga a someter al paciente a una cirugía para realizar el diağóstico cuando se encuentran las características adherencias. Si sospechamos la enfermedad mediante las pruebas comple⿳亠㐅⿵冂ntarias, podemos intentar tratarla con antibióticos.

PALABRAS CLAVE: Colecistectomía. Fitz-Hugh-Curtis. Clamidia.

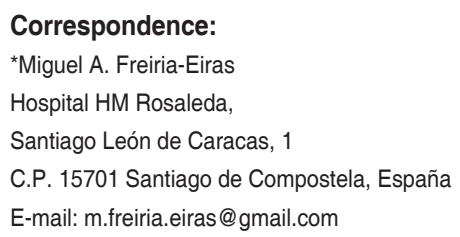

Cir Cir. 2018;86:404-407

Contents available at PubMed www.cirugiaycirujanos.com 


\section{Introduction}

Fitz-Hugh-Curtis syndrome (FHCS) is a type of perihepatitis that causes inflammation of the liver capsule without affecting the parenchyma. This syndrome owes its name to Curtis, who in $1930^{1}$ reported inflammation of the hepatic capsule with adhesions to the diaphragm in a patient already affected by salpingitis, and to Fitz-Hugh, who in $1934^{2}$ identified the Neisseria Gonorrhoeae bacillus as a cause of adhesions between the liver and the diaphragm with the characteristic shape of "violin strings".

This liver inflammation is thought to be caused by hematologic or lymphatic migration of pathogens from a previous pelvic infectious process.

Most FHCS cases occur in young women of childbearing-age diagnosed with pelvic inflammatory disease or acute salpingitis, accompanied by pain in the upper right quadrant of the abdomen. Occurrence in males is highly uncommon; only nine cases have been reported in the literature (Table 1).

Initially, the two most commonly identified microorganisms were N. gonorrhoeae and Chlamydia trachomatis but, currently, other sexually-transmitted bacteria are known to cause the inflammatory process ${ }^{3}$.

The main symptom is right upper quadrant abdominal pain, which often leads to confuse FHCS with a biliary disease, associated with pelvic inflammatory symptoms in women. In men, pelvic manifestations may be absent.

On imaging tests, liver capsule enhancement can be found in an abdominal computed tomography (CT) scan with IV contrast ${ }^{4,5}$.
Herein, we present the case of an elderly male patient diagnosed with FHCS during a laparoscopyl for a biliary pathology.

\section{Clinical case}

Eighty-one-year-old male who attended the emergency department referring continuous abdominal pain in the mesogastric area, which radiated like abelt around the trunk, with abdominal distension and nausea, without fever, jaundice or choluria. He was hemodynamically stable.

He had a personal history of high blood pressure, hypercholesterolemia, partial cystectomy for bladder cancer, chronic obstructive pulmonary disease and diverticulosis of the sigmoid colon.

Blood tests showed 9800 white blood cells with $79 \%$ of neutrophils; the rest of the blood count and bipchemistry results were normal, except for a slight amylase elevation, $125 \mathrm{U} / \mathrm{L}$ (23-85). Abdominal-CT revealed acute pancreatitis (Balthazar $\mathrm{C}$ ) on the pancreatic tail. Magnetic resonance cholangiography showed no evidence of choledocholithiasis or liver pathology; gallbladder sludge and pancreatic tail inflammatory process stood out. The patient was treated with conservative measures and was uneventfully discharged on the tenth day.

One week later, the patient returned to the emergency department for the same abdominal pain on blood tests, amylase values of $87 \mathrm{U} / \mathrm{L}$ and lipase at $813 \mathrm{U} / \mathrm{L}(0-160)$ stood out. Abdominal CT showed a nodular lesion on the pancreatic tail, with no data of inflammation or perihepatic fluid. The patient was

Table 1. Fitz-Hugh- Curtis syndrome published cases in men

\begin{tabular}{|c|c|c|c|c|}
\hline Authors and year & Age (years) & Presentation & Treatment & $\frac{0}{\circ}$ \\
\hline Kimball and Knee, $1970^{13}$ & NA & NA & NA & $\stackrel{0}{\simeq}$ \\
\hline Francis and Osoba, $1972^{14}$ & 25 & Abdominal pain and urinary symptoms & Antibiotics & อั \\
\hline Davidson and Hawkins $1982^{15}$ & 35 & Right preural pain, proctitis and urethritis & Antibiotics & $\varepsilon$ \\
\hline Baek et al., $2010^{16}$ & 35 & Right quadrant pain and urinary symptoms & Antibiotics & $\underline{\underline{0}}$ \\
\hline Saurabh et al., $2010^{10}$ & 29 & Right quadrant pain & Surgery & 으 \\
\hline Rouhard et al., $2014^{12}$ & 45 & Right quadrant pain & Surgery an & biotics \\
\hline Nardini et al., $2015^{11}$ & 26 & Abdominal pain and history of genital infection & Antibiotics & $\frac{n}{c}$ \\
\hline Jeong et al., $2015^{17}$ & NA & NA & NA & $\begin{array}{l}+ \\
4 \\
0\end{array}$ \\
\hline Yi et al., $2015^{6}$ & 60 & Right quadrant pain & Antibiotics & $\frac{t}{\sigma}$ \\
\hline Freiria-Eiras, 2017 (current) & 81 & Right quadrant pain & Surgery an & bioftics \\
\hline
\end{tabular}


treated as an acute pancreatitis case, had a good evolution and was discharged at twelfth day.

Subsequently, elective cholecystectomy was carried out with the laparoscopic approach. After pneumoperitoneum was produced, strong adhesions were found (Fig. 1) between the hepatic capsule and the diaphragm (resembling "violin strings"), which are characteristic of FHCS. Cholecystectomy was performed and adhesions were sectioned. In the postoperative period, he was treated with levofloxacin, $500 \mathrm{mg} / 12$ hours for 7 days. The patient recovered uneventfully and was discharged 24 hours after surgery, with good recovery at home.

\section{Discussion}

We usually refer to FHCS as inflammation of the hepatic capsule associated with pelvic inflammation, with this condition occuring more commonly in women of reproductive age. According to $\mathrm{Yi}$ et al. ${ }^{6}$, this syndrome can be divided in two phases: an acute phase, where the characteristic findings of an exudative inflammation of the liver capsule are observed, with acute abdominal pain that can radiate to the right shoulder, and a chronic phase, where liver inflammation and exudates create liver adhesions to the diaphragm in the characteristic shape of "violin strings". These adhesions should not produce symptoms, but in persistent cases of pain in the upper right quadrant, some authors, such as Owens et al. ${ }^{7}$, recommend their resection.

In most cases, diagnosis of the microorganism causing the infection is not reached, since patients are usually empirically treated with antibiotics when an infectious biliary pathology is suspected. The way the pathogen spreads from the pelvic area is still unclear, especially in males, since most have no infectious symptoms in the genitals.

The most important for a correct diagnosis is suspicion of the disease by the clinician. This is often difficult, since most cases in men are mixed-up with biliary pathologies, such as acute cholecystitis, and many times the diagnosis is established in the surgical act itself. If an abdominal CT is requested, a radiologist with experience may suspect perihepatitis if liver capsule enhancement is observed when the study is performed with intravenous contrast in the arterial phase. In our case, we did not visualize said enhancement, but a perihepatic fluid collection was revealed, which was consistent with the presence of abdominal pain.

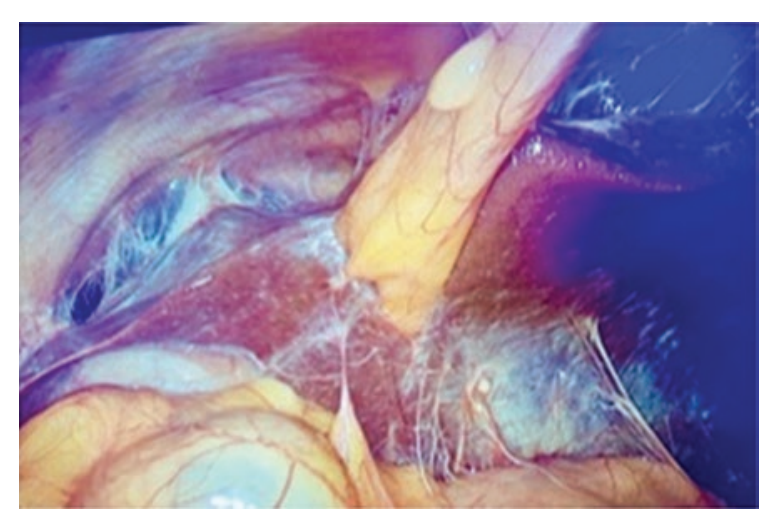

Figure 1. Characteristic violin string-like adhesions.

If an accurate FHCS diagnosis is established through patient clinical data and complementary têsts, treatment with empirical antibiotics can be tried wivithout the need to identify the causative microorganism ${ }^{8}$. If despite a correct antibiotic treatment abdominal pain persists, resecting the adhesions created betweenthe liver and the diaphragm can be tried, as Reichertand Valle suggest ${ }^{9}$.

As we have already mentioned, this syndrome is quite uncommon in males. We have picked up the cases published in the literature, which we summarize in table 1, and comment some of them are belows

Yi et al. ${ }^{6}$ published in 2015 the case of a 60 -yeareold male who presented with pain in the upper right quadrant and a history of gonorrhea, who was diagnosed by his symptoms and abdominal CT results.

Saurabh et al. ${ }^{10}$ published in 2012 the case of a 29 -year-old young patient with an episode of pain in the right quadrants, diarrhea, nausea and vomiting, who underwent surgery for pain persistence without the cause being found in complementary tests, कut with the characteristic violin string-like adhesionscbetween the liver and the diaphragm being detected.

Nardini et al. ${ }^{11}$ described in 2014 the case of a 26-year-old male who attended the emergency $₫$ department with complaints of right upper quadrantabdominal pain, accompanied by painful urination and a recent history of risky sexual encounters. On abdëminal ultrasound, a small amount of perihepatic fluid was observed, and urethral smear tests were positive for C. trachomatis and N. gonorrhoeae. The patient was satisfactorily treated with antibiotics

Finally, we should point out the case published in 2014 by Rouhard et al. ${ }^{12}$, about a 45 -year-old man with chronic pain in the upper right quadrant, who underwent exploratory laparoscopy, with the characteristic violin string-like adhesions being visualized. The patient was successfully treated with antibiotics. 
In our case, we have presented an elderly patient with signs and symptoms suggestive of pancreatic and biliary pathology. Imaging tests did not lead to suspect the possibility of FHCS, and the diagnosis was established after initial laparoscopy for a cholecystectomy. On subsequent examinations, we requested serology for sexually-transmitted diseases, with all testing negative, except for antibodies against C. trachomatis. When the patient, was questioned, he referred never having had risky sexual practices, but he mentioned having had urinary problems for about 6 months. The cause of $C$. trachomatis infection was not found, but we suspected that this pathogen had caused the abdominal pain and inflammation conditions the patient experienced.

\section{Conclusion}

FHCS is an infectious process where perihepatitis is caused by a genitourinary infection. It is more common in the female gender. Only few cases have been described in males. Perihepatitis characteristic image are violin string-like adhesions between the hepatic capsule and the diaphragm.

If this syndrome is suspected based on patient clinical signs and symptoms and imaging exams, antibiotic treatment targeting the more common microorganisms ( $N$. gonorrhoeae and $C$. trachomatis) is recommended; however, the diagnosis is often established during the surgical act motivated by suspicion of biliary pathology, when the characteristic adhesions between the liver and the diaphragm are discovered.

We present a case of FHCS in an 81-year-old male caused by $C$. trachomatis, in whom the characteristic adhesions between the liver and diaphragm were found after a laparoscopy was performed in a cholecystectomy procedure for the treatment of reeurrent pancreatitis.

\section{Conflicts of interests}

The authors declare that they have no conflicts of interest.

\section{References}

1. Curtis AH. A cause of adhesions in the right upper quadrant. JAMA. 1930;94:1221-2

2. Fitz-Hugh Jr T. Acute gonococcic peritonitis of the right upper quadrant in women. JAMA. 1934;102: 2094-6.

3. Wang SP, Eschenbach DA, Holmes KK, Wager G, Grayston JT. Chlamydia trachomatis infection in Fitz-Hugh-Curtis syndrome. Am J Obstet Gynecol. 1980;138:1034-8.

4. Wang CL, Guo XJ, Yuan ZD, Shi Q, Hu XH, Fang L. Radiologic dîgnosis of Fitz-Hugh-Curtis syndrome. Chin Med J (Engl). 2009;122:741-4.

5. Nishie A, Yoshimitsu K, Irie H, Yoshitake T, Aibe H, Tajima T, et al. Fitz-Hugh-Curtis syndrome. Radiologic manifestation. J Comput Assist Tomogr. 2003;27:786-91.

6. Yi H, Shim CS, Kim GW, Kim JS, Choi IZ. Case of Fitz-Hugh-Curtis syndrome in male without presentation of sexually transmitted disease. World J Clin Cases. 2015;3:965-9.

7. Owens S, Yeko TR, Bloy R, Maroulis GB. Laparoscopic treatment of painful perihepatic adhesions in Fitz-Hugh-Curtis syndrome. Obstet Gynecol. 1991;78:542-3.

8. Peter NG, Clark LR, Jaeger JR. Fitz-Hugh-Curtis syndrome: a diağnosis to consider in women with right upper quadrant pain. Cleve Clin "JMed. 2004;71:233-9.

9. Reichert JA, Valle RF. Fitz-Hugh-Curtis syndrome. A laparoscopic approach. JAMA. 1976;236:266-8.

10. Saurabh S, Unger E, Pavlides C. Fitz-Hugh-Curtis syndrome in a-male patient. JSCR. 2012;3:12.

11. Nardini $P$, Compri M, Marangoni A, D'Antuono A, Bellavista S, Calvanese $C$, et al. Acute Fitz-Hugh-Curtis syndrome in a man due to gondococcal infection. J Emerg Med. 2015;48:e59-62.

12. Rouhard $S$, Maldague $P$, Ramboux A. Fitz-Hugh-Curtis syndrome-in a man. Endoscopy. 2014;46 Suppl 1 UCTN: E1.

13. Kimball MW, Knee S. Gonococcal perihepatitis in a male. The Fitz- $-\mathrm{Hu}$ gh-Curtis syndrome. N Engl J Med. 1970;282:1082-4.

14. Francis TI, Osoba AO. Gonococcal hepatitis (Fitz-Hugh-Curtis syndrome) in a male patient. Br J Vener Dis. 1972;48:187-8.

15. Davidson AC, Hawkins DA. Pleuritic pain: Fitz Hugh Curtis syndrome in a man. Br Med J (Clin Res Ed). 1982;284:808.

16. Baek HC, Bae YS, Lee KJ, Kim DH, Bae SH, Kim DW, et al. A case of Fitz-Hugh-Curtis syndrome in a male. Korean $\mathrm{J}$ Gastroenterol. 2010;55:203-7.

17. Jeong TO, Song JS, Oh TH, Lee JB, Jin YH, Yoon JC. Fitz-Hugh-Eurtis syndrome in a male patient due to urinary tract infection. Clin Imaging. 2015;39:917-9. 